\title{
Analyzing the Detailed Methods and Measures of Cultivating Children's Creativity with Activities in Public Art
}

\author{
Nie Hong \\ Department of Art \& Design,Wuhan University of Science and Technology, Wuhan City, Hubei Province, China \\ 2395471318@qq.com
}

\begin{abstract}
From the aspect of how teacher should cultivate children's creativity with the teaching of public art, the paper discusses the detailed methods and measures of cultivating children's creativity, including creating suitable environment for cultivating children's creativity, holding activities that can cultivate children's innovation personality, and inspiring children's creation awareness and cultivating children's creativity with art teaching.

Index Terms - Art teacher, the creative, the creative environment, Imagination, The creative ability
\end{abstract}

\section{Introduction}

Recently, more and more researchers conducting researches about art teaching for children from different aspects. The results of such researches show that art teaching for children is widely affected by philosophy, psychology, society and culture background. Some researchers begin to focus on the cognition development of children in art, the role of adults in guiding cognition development of children and the mutual development between these two factors, etc. Child painting is a visual language to express ideas. Children can express their psychological need, mood and their understanding of surrounding by painting. Art teaching play a special and unique role in cultivating children's creativity.

\section{Creating an Environment of art Teaching, Which is Favorable to Children's Creativity Development}

Guideline of Nursery Education says:" Environment is an important education resource; therefore, creating and using favorable environment can effectively improve the development of children." Many researches and studies show that suitable learning environment is help to the improvement of children's creativity. The responsibility of teacher is to create a sound environment which can help the children to release their potential creativity.

\section{A. Classroom is also the studio. Creating material environment which can trigger exploration and children's interests in creation}

"Material environment" refers to the necessary material conditions for the children to express novelty and unique thoughts, and produce "fruit" with creativity. The studio set in the public art space is opened with students from different age ranges. All the students will finish painting according to their skills. And then the students will be divided into different groups according to the content and style of the art activities.
A sound art teaching proposal should be able to ensure that different materials should be easily reached and used immediately. When different art tools and studio are arranged orderly and conveniently, teachers would be relaxed and willing to conduct as many art activities as possible. In addition, kids will be strongly urged by the surrounding environment and atmosphere to participate into experiments and innovative activities. In a studio, four different types of space should be considered:

(1) Space for storing materials, tools and other stuff.

(2) Space for keeping unfinished works.

(3) Space for displaying graphic works and 3D works completed by children.

(4) Space for showing interesting objects and copies related to arts.

\section{B. Creating a relaxed, harmonious, free and democratic psychological environment to release the potential creativity of children}

"Psychological environment" refers to the sum of many factors, including factors triggering the generation of innovation awareness, motivating creation motive, enriching creative mood, encouraging creative imagination and so on. Many humanistic psychologists found that creativity can only be generation without any external restriction. Getting rid of restriction and obtaining freedom are benefit for unconscious and vigorous thoughts, which help people to obtain creativity. Torrance considered "friendly and relax" environment does well to the development of children's creativity. Art teaching activities allows children to obtain freedom, so as to grow and make progress. Children's art creation and design activities can not only cultivate a healthy mind, but also have the following benefits:

(1) Confirmation of self-value: due to the great freedom of creation and design, children have a free mind, meet the desire of free imagination and enhance their confidence in personality development during the process of creation and design.

(2) Opening ego: painting is a visual language and nonverbal expression; it is also an expression of the mind. Connecting the internal world with the external one through such non-verbal and perceptual painting, children can learn how to release the internal pressure and anxiety and open their mind to others in an environment without any scrupulousness and restriction. 
(3) Safety and being respected. In art, there is no judgment of "being similar" or "being different". It's an expression of oneself and a self-creation. It is a process of making progress of heart and soul in a safe, free and pressureless environment full of respect and caring.

(4) Stimulating the intellectual development: the individuals are confident and with self-approval. In a safe atmosphere with respect, the individuals can open themselves and express themselves fully. At the same time, the learning ability, creativity, abstract thinking ability and the adaption of the environment will be improved at the same time. To be specific, the individuals can improve their skills in reasoning, judging and learning.

(5) The improvement of adjustment: children can express their confusion and concerns through painting, so as to keep their mind in peace and reserve a relax space for the individual mood and mood.

\section{The parent-child education environment of art creation and design activities changes the concept of parent-child education}

In modern society, both parents have their own jobs, so they are busy all the time and don't have a very clear and sound concept in educating the children. Parents should ask themselves that whether they have the patient to have an indepth conversation with the children and whether they can closely observe the inner demand of children. Many parents just use their own expectation to educate the children, or want the children can make up their own disadvantages. All these problems deserve our consideration.

Many art teaching activities, including painting, clay sculpture, design and knitting, etc., are suitable for parentchild communication. Besides, these activities are affordable and interesting. With a pen and a piece of paper, the children can express the deep feeling of their mind. Spending a short time with heart and soul with the children, they will feel safe. The accomplishment and encourage to the results of creation and design done by the children, the children will be confident. During the growth of children's mind, parents are not only carers, but also guiders. When the parents adjust the education concept, know more the inner world of the children and understand the pictures painted by the children, the children would be more willing to express their feelings and ideas, so as to improve the parent-child relationship and interaction.

\section{Holding Activities Cultivating the Innovation Ability and Spirit of the Children}

\section{A. Cultivating children's independent thinking}

Independence here refers to the particularity or uniqueness of thinking. It means that the children have their own opinions and ideas. These ideas are not blindly following others or interfered by the others. If children can stick to their own ideas, it would be helpful to innovate. For example, a child have painted a tree with pears, apples, and oranges in it. He explained:" I hope there is a tree which can have different fruits in different colors." In his work, there are blue apples and red bananas. In such circumstance, the teacher should approve and encourage such unique thinking.

\section{B. Protecting the curiosity of the children.}

Psychologists home and abroad conduct quite a large amount of researches in the relations between curiosity and creativity. Torrance, Mackinnon and others found that the creative children always have strong curiosity. Curiosity is one of the psychology features of the creative children. If children are very curious about something, they may use their own way to explore and discover. Children between 3-6 years old may have innocent fantasy in their mind due to curiosity, which should not be considered as "nonsense" by the adults. Instead, the adults should try to find out the sprout of creation in such fantasy, and then correctly lead and courage such behaviors, so as to allow it to develop reasonably.

\section{Cultivating strong will of creation}

The creative people usually have a strong will. If they don't have the strong will, they may give up on the half way, so that they cannot go forward towards their dream and hardly innovate. Take clay sculpture of art teaching activity as an example. At the very beginning, children are very curious and they would like to have a try. However, clay sculpture needs not only patient but also perseverance. Sometimes the clay sculpture may crash and the efforts of children would be in vain. At this moment, teachers should encourage them to stick to their goal and finish their work. When the spirit of perseverance can be developed, their creativity will be stimulated. When children experience failure, teachers should tell them that "everyone has experience failure before". Even we can set some scenarios with obstacles for children, so that the children would experience some frustrations, and the teachers can have a higher expectation for them. At the same time, teachers should encourage the children to be confident by saying "you can make it", "please try again", and "try it one more time", so as to cultivate a strong will of children to be persevering until realizing the goals. Teachers should usually tell children "you will be successful".

\section{Support the exploration of the children}

As a proverb goes, "It is better to teach a man to fish instead of giving him fish." On one hand, teachers should teach knowledge to children; on the other hand, they should support the exploration spirit of children. For example, when visiting the suburban area, teachers can cover eyes of children and let them touch tree with their hands, and then paint the trees according to their memory. With this method, the content of the painting can be rich, interesting and vivid. In additional, the pictures show the world in the eyes of children instead of the world in the eyes of teachers. Such pictures are the real demonstration of the children's understanding and experience of the world. In this way, the creativity of the children will be enhanced.

\section{Teachers Should Cultivate the Creation Awareness and the Creativity of Children with Art Teaching Activities}

The current art teaching activity is easily neglect the cultivation of children's creativity. The traditional art teaching 
focuses on rational knowledge and skills. Such teaching overlooks the observation, thinking and imagination of children, so the pictures painted by children are in the same pattern, fixed, and lacking personality and self-experience. Many art teachers think that teaching children how to paint means ask them to imitate the picture painted by teachers. So they just hang a sample, and ask children to copy the sample. Such training neglects the cultivating of creative thinking for the children; and creativity is just the "life" of art activities. Inspiring the mind of children and cultivating the creative thinking of children are the keys of developing the creating thinking of children.

\section{A. Triggering children's interest into painting}

a) Cultivating the observation and discovery ability of children with guidance.

Children are very interested in painting, and they are excited about what they created. Guiding observation is the key of cultivating the cognition and awareness of children. The observation of children usually are not very comprehensive. However, if children are guided to observe the lines, shapes, colors, light and shade, characters, and proportions and sizes of objects, their cognition will be fully developed. As long as they know more details of objects, their works are more detailed, so that the different visual images made by different children are more different.

b) Giving full play to the imagination of children.

When painting, there are three ways of forming image, namely: recalling, observing and imaging. When children are required to paint object with vague memory, the results are usually disappointed. When children are required to paint someone or something that play an important role in their life, the images are detailed, even with some exaggerated parts showing the specific interest and awareness of the young "artists". For example, the tongue of a friendly dog may occupy the largest part; a pianist may have a lot of figures for each hand.

c) Accumulating creation experience from different ways.

Visual experience: video, slide, picture and object are important means of guiding the observation of children. Personal experience: including visiting zoo, farm, garden house, vegetable field and so on. Material experience: allowing children to use the material to create directly. Children would understand the richness of colors by showing the changes of mixing two or more different colors. Sensing experience: obtaining external information and training acute sensation by fully using different sense organs.

\section{B. Cultivating vivid idea by guiding children to find out topics} of painting from their life

Painting object in the real world in the best way to improve the visual perception and visual cognition. For example, teachers can teach children how to paint a leaf. After completing, teachers can give out several leaves for observing. Some leaves have dark color and some leaves have light color, and some leaves are even in yellow, gold or red. At this moment, if the children are required to paint another leaf, they can paint a more vivid and accurate one because they have observed the real leaves and have a better understanding of leaves. Painting object in real life based on observation can enhance the coordination among perception, eye and hand. Pictures painted by children based on observation can be surprised and unique at the same time. Even the object is from the real life, the eventual image is the demonstration of children's personal thinking.

\section{When conducting art teaching activities, exploring new methods}

a) We can realize the wonderful world in the mind of children by listening to the ideas of children. In this way, teachers can determine the topic of painting and design the teaching activities.

b) Encouraging children to find out the differences among different objects based on observation and comparison. For example, visiting the suburban areas during the changing of seasons; observing the nose of elephant, the neck of giraffe, the ear of rabbit and so on to enhance the impression of children in the main characters of objects.

c) In painting activities, teachers can encourage children to adopt a different thinking in painting via posting questions and suitable inspiration, so as to prevent a rigid and fix thinking model. For example, during the painting activity named The Sun, the teacher asked that "does the sun only have a fixed color?" And then a boy answered:" the sun is green in summer, so we don't feel hot; the sun is red in winter, so we don't feel cold." After that, children chosen different colors to paint the sun according to their own decision. After that, the teacher asked another question:" Does the sun always have a round face all the time?" And then children painted their own suns in different shapes, like triangle, trapezoid, with short hair, with curly hair and so on. With questions, children had different imagination and then painted their exaggerated and unique suns. If the imagination of children are accomplished by teachers, children would be more active in responding questions posted by teachers. And the teachers can use questions to guide children to have free and exaggerated imagination towards objects in the real life, so as to cultivate their creation awareness. The innocent and unique ideas of children are very inspirational and excited.

\section{Training the creative thinking of children}

a) Designing art teaching according to the perception ability rules of children to art

We played some expressive, sad or bright music, then asked children to paint their experience with different colors. Some timid and obedient girls used small square shape as the main elements in pink, baby blue and purplegreen; some bold and out-going girls preferred chunks and lines in bright red, blue and green color; some aggressive boy chose chaotic lines with sharp angles in strong colors like dark red, black and dark green and so on; and some introversive boys favored colors like yellowish brown, brown and olive green. When judging the art perception of children, there is no right or wrong according to the subject awareness. Children should be allowed to experience art in a self-expression manner. 
b) Designing art teaching according to the rules of children's imagination development.

During the painting, teachers should guide children to give full play to subjective consciousness and imagination, so as to emphasis their personality in their painting. For example, during the line painting training, we designed stories related to the images. In the class, teachers told stories, while guided children at the same time. With the stories told by teachers, children could have rich imagination and complete their painting. When the painting was finished, the stories ended. Different children have different lives, observations and imaginations, so they painted different pictures, which are very interesting.

\section{E. Designing art teaching as games to inspire children in creating}

a) Integrating abundant cognition activities into teaching. For instance, going to the suburban area with children during the spring time, so as to observe how the peach blossom and magnolia flower come out and the wings of butterflies in the flowering shrubs. In this way, children can not only capture the momentary changes of objects, but also allow children to have a long-term observation. By observing the life habit and motions of animals in the zoo, children would know the Mother Nature and people's life are the resources of creation.

b) Playing games with children based on the teaching and allowing children to increase their knowledge through game playing. During the teaching, in order to let children to understand the color changing, teachers can have three color buckets in red, yellow and blue with hoodles. The collision of hoodles would produce different colors. Games would trigger the curiosity and interests of children. With games, a challenging lesson about color changing will be completed with fun.

\section{F. Objectively and reasonably commenting on children's paintings}

Comment is an important step. Teachers should change their mind. Criteria for cultivating professional painters should not be used in judging children's painting. Art teaching should be based on release potential ability and improve children's quality. Teachers should not pay attention to a specific student only; each child should receive art education.
To do list

\begin{tabular}{l|l|}
\hline A. Art works of children are record of their personality & A \\
\hline $\begin{array}{l}\text { B. The process of creating and designing is important in the growth } \\
\text { of individuals }\end{array}$ \\
$\begin{array}{l}\text { C. Understanding the unique experience and expression of children } \\
\text { in arts }\end{array}$ \\
\hline $\begin{array}{l}\text { D. Please congratulate children when they express their successful } \\
\text { experience }\end{array}$ \\
\hline $\begin{array}{l}\text { E. Encouraging children to appreciate and respect each other's } \\
\text { performance }\end{array}$ \\
\hline $\begin{array}{l}\text { F. Allowing children to have different experiences, so as to improve } \\
\text { their skills }\end{array}$ \\
\hline G. Encouraging children to spontaneously express themselves \\
\hline H. Providing a space for creating & \\
\hline
\end{tabular}

Not to do list

A. Don't correct children's works or help them in creating, nor force children to accept your personality

B. Paying unreasonable attention to the results of creation

C. Don't expect the arts of children echoes your opinion

D. Provide unreasonable and irrational accomplishment to works of children

E. Don't compare works of children

F. Don't instruct children that how to paint

G. Don't encourage children to create with the prize

H. Don't restrict the environment for creating by children

\section{Conclusion}

A philosopher has said that, it is clever to have questions about things you don't know; it is smart to explore the future things; it is intelligent to challenge the previous conclusion; it is wise to innovate for the future. Curiosity and adventure in the childhood breed invaluable innovation awareness and innovation spirit. We should grab every opportunity to switch such innovation awareness and innovation spirit into creativity, so as to lay a solid foundation in cultivating talents with creation awareness.

\section{References}

[1] Guideline of Nursery Education, Department of Basic Education of the Ministry of Education, jiangsu Education Publishing Press.2002.

[2] Tang Linlan, Cultivation of Children's Creativity by Teachers. Journal of Chongqing Vocational and Technical College. Vol 14. No 3. 2005(7)

[3] Lin Chongde, Developmental Psychology, People's education Press, 2009(3).

[4] Fan Qiongfan, Psychological Analysis and Tutorship in Children's Painting, Taibei: Psychnology Press.1999(5)

[5] Barbara Herberholz, Early Childhood Art Creative Education, Guangxi Fine Arts publish press. 2009(12) 